\title{
A Study on the Case of Kalbushan Jadev from the View of International Law
}

\author{
Professor DENGLIE \\ Chair of International Law Development, Law School, Zhongnan University of Economics \& Law \\ REHNA GUL \\ PhD. Scholar at the School of Law, Zhongnan University of Economics and Law, China
}

\begin{abstract}
Kulbushan Yadhav Case is a unique case in which an Indian spy was caught during the operation of security forces in Pakistan in 2016. He was allegedly involved in sponsoring terrorism in the provinces of Baluchistan and Sindh in Pakistan. He confessed all the offenses committed by him which was telecasted on TV channels across the world. Kulbushan Yadhav was serving Commander of Indian Navy that confessed that he funded BLA and BRA named illegal terrorist organizations in the Province of Baluchistan while working for Indian Intelligence Agency RAW. He further confessed that he visited Karachi twice and gathered intelligence pertaining to Pakistan's Navy. He also admitted that there are many other RAW agents like him working in He was sentenced to death in Pakistan. India denied the confession of Kulbushan Yadhav again and again. India approached International Court of Justice in 2017 which initially stayed the execution of death sentence against Kulbushan Yadhav. In the final verdict of the case the International court of Justice (ICJ) granted consular access to India and ordered review of death sentence of Kulbushan Yadhav in July 2019. India's plea for the release of Kulbushan Yadhav was rejected.

This case was contested by India Legal team headed by Mr. Harish Salve and Pakistan's Legal Team headed by Mr. Khawar Qureshi. India's stance was that Pakistan is denying consular access to India which is right of accused under the provisions of Vienna Convention. The proceedings of the case initiated in May 2017 and finally the case got decided in 2019. In this article we have used different spellings of the name of Kulbushan Yadhav (Jadhev) as this name is written both ways in India and Globally.

Pakistan and India are neighboring countries located in sub-continent. Both got independence from Great Britain by virtue of Partition Act 1947. India never accepted Pakistan's independence because of which it made things worse for Pakistan since the independence times. Both countries fought fierce wars against each other in 1948, 1965, 1971 and 1999. Pakistan also lost half of the country which was East Pakistan and later it becomes Bangladesh in 1971 because of the interference of India in the internal affairs of Pakistan.

Pakistan came into being on the doctrine of Two Nation Theory which was given by Dr. Allama Muhammad Iqbal at his historic speech at Allahabad India in 1931. He was a renowned poet also known as poet of the east. According to the two nation theory there are two nations living in Indo-Pak Subcontinent which are different in their cultures, religions, morals, language and lifestyles. They cannot live together because of which there is a dire need of separate homeland for Muslims living in India. This two nation theory becomes the basis of division of India and creation of Pakistan in 1947.

When Pakistan lost East Pakistan province, the then Primemininster of India Mrs. Indira Gandhi said "Two Nation Theory has been drowned in Bay of Bengal". India has the same approach of destroying rest of Pakistan because of which it keeps sending its agents in Pakistan to destabilizing it. Kulbushan Yadhav is one of such agents which got arrested after considerable time. He was involved in sponsoring terrorism activities in Pakistan especially in the provinces of Baluchistan and Sindh.

Pakistan and India are both Nuclear Armed Nations. Both the countries are well equipped with the state of the art machinery, fighter jets, strong armed forces and capability to destroy each other. There are border disputes also between both countries especially because of disputed territory of Jammu \& Kashmir. If agents like Kulbushan Yadhav are not restrained from interfering in the matters of Pakistan, someday this world may become an unsafe place to live.
\end{abstract}

Keywords: - Kulbushan Yadhav Case, Indian Spy Case, Consular Access Latest Judgment, Indian Terrorist Spy Case, Cross Border Terrorism by India, Indian Sponsored Terrorism

DOI: $10.7176 / J L P G / 97-03$

Publication date:May $31^{\text {st }} 2020$

\section{HISTORICAL BACKGROUND}

Kulbushan Jadev was not the first agent that got arrested in Pakistan. Rather before him many other agents of RAW (Research and Analysis Wing) were arrested from Pakistani soil. One of them was Ravindra Kaushik. He was born in 1952 in India with this name. Later he was given a Muslim name of Nabi Ahmed Shakir and he went through circumcision to make sure that he appeared as a Muslim if get caught. 
Mr. Kaushik received training at Delhi. He was a native of Rajasthan area because of which he was well conversant with Punjabi language. He was taught Urdu for improving communication skills in Pakistan. He was sent to Pakistan in 1975 at the age of 23 only. He further studied at Karachi University and obtained LLB degree from there. He was so brilliant that he managed to get a job at Pakistan army as a clerk. He married a Pakistani girl that was daughter of a tailor working in Pakistan Army. He also got a son from that wife that died later in 2013. While working for Pakistan Army he shared secrets of Pakistan Army with Raw between 1979 to 1983. Indian Intelligence agency initially regarded his services and he was named as Black Tiger in India. Later a movie named "Aik tha Tiger" was also made on him in the year 2012. He was apprehended in 1983 and was sentenced death in 1985. However later his punishment was converted into life imprisonment by the Supreme Court of Pakistan. He spent rest of his life in different jails of Pakistan and finally passed away in 2001 due to a heart disease. He was so resourceful that he was in habit of sending letters to Indian Intelligence Agency RAW and his family from jail in Pakistan. India never admitted that he was Indian Agent. Indian Government did no efforts to rescue him. In one of famous letters to his mother he wrote "Is this the reward a person gets for sacrificing his life for a great country like India?"

Another agent sent by India in 1983 was Mr. Inayat Masih. He was arrested in Pakistan and after arrest he exposed Mr. Kaushik. Another famous RAW agent was Sarabjit Singh. He was involved in terrorism activities in Punjab in 1990. He was sentenced death by Military Court and later is death punishment was upheld by Supreme Court of Pakistan. However, his death punishment was not executed till 2013 when one day he was attached by other prisoners in jail and he died in a Hospital later. Initially he was disowned by India like all previous agents but on his death India Mourned for 3 days and paid compensation to his legal heirs. Kashmir Singh was an Indian Spy that spent 35 years in Pakistani Prison but was released due to Presidential Pardon in Good Gesture. Similarly Pakistan also released Indian Agent Surjeet Singh in Goodwill gesture. Ramraj, Ram Prakash, Om Prakash, Vinod Sawhney, Suram Singh, Balwir Singh, Devut, Sunil, Daniel, Tilakraj and Satpal were some of the other Indian agents that were caught and most of these were returned by Pakistan as Goodwill Gesture.

\section{KALBUSHAN YADEV CASE: INTERNATIONAL COURT OF JUSTICE}

Kulbushan Yadhav Case initiated with the arrest of Kulbushan Yadhav from Pakistan in March 2016. Initially India didn't admitted or denied the video footages of confession of Kulbushan Yadhav shown on News Channels around the world. He was trialed by Military Court in Pakistan and announced death penalty on the allegations of Espionage and Terrorism in April 2017.

On $8^{\text {th }}$ May 2017 India filed an application at the International Court of Justice claiming the detention of Mr. Yadhav illegal and in violation of the provisions of Article 36 of the Vienna Convention on Consular Relations (1963). Further India demanded release of Kulbushan Yadhav. Pakistan lost most of the case because of voting at the International Court of Justice. India was granted consular access to Mr. Yadhav while International Court of Justice did not released Mr. Yadhav rather it instructed Pakistan to reconsider and review the sentence of the accused. The final verdict of the case was announced on $17^{\text {th }}$ July 2019 by the International Court of Justice.

\section{LEGAL STANCE OF INDIA AND PAKISTAN \\ Pakistan's Stance}

In the arguments of the case Pakistan mostly argued on the non-admissibility and non-jurisdiction of International Court of Justice. The strongest argument of Pakistan was that Mr. Jadev was engaged in terrorism activities because of which Article 36 is not applicable on him. Pakistan is not legally bound to give consular access to Mr. Jadhav as he was a terrorist. However, a new precedent is made in the Judgment of this case which granted Consular Access to a terrorist in the following words:-

"Having found that none of the arguments raised by Pakistan could be upheld, the Court concluded that the Vienna Convention was applicable in the case, "regardless of the allegations that Mr. Jadhav was engaged in espionage activities".

This is probably the first case in the history of the world in which a terrorist has been given rights under the Vienna Convention through a Judgment of International Court of Justice.

\section{India's Stance}

India mainly argued the case on the ground of violations of Article 36 of Vienna Convention by Pakistan. India tried its level best to make out a case against Pakistan for the release of Mr. Jadev and for declaring the decision of conviction of Mr. Jadev as null and void. However, International Court of Justice fairly declined India's plea of releasing Mr. Jadev.

The decision was one such decision which made both the countries happy as they both considered that they have won the case. 


\section{JURISDICTION OF INTERNATIONAL COURT OF JUSTICE}

The International Court of Justice can entertain two kinds of cases between states. These include:-

1. Contentious Cases

2. Advisory Opinions

The first kind of cases include the following kinds of cases:-

a. Special Agreements

b. Compromisory Clause

c. Optional Clause Declarations

d. Doctrine of Forum Prorogatum

In these kinds of cases the rulings passed by the court are of binding nature. The parties in such kinds of cases either agree or they agreed in past to accept the rulings of the court. At times there are clauses in agreements that also allow the International Court of Justice to decide matters between states signing such agreements. In majority of the cases of contentious nature, the ICJ lacks jurisdiction. In most cases the jurisdiction is challenged or the question of jurisdiction is raised at preliminary stage. In some cases the States also give consent to agree to the decision of International Court of Justice. That makes such decisions binding on the states also. The International Court of Justice mainly derives jurisdiction from Article 36 in this regard.

The second kinds of cases which are advisory opinions are not binding on parties. These cases are usually instituted on the request of UN General Assembly. Sometimes the advisory opinions are also binding on some institutions, agencies or the states. Usually the advisory opinions are not authoritative because of which they are highly respected in International Law.

Kalbushan Jadev Case is one such case in which the Jurisdiction of International Court of Justice has been discussed in detail. The International Court of Justice has made its jurisdiction under Article 36 in this case.

\section{VIENNA CONVENTION ON CONSULAR RELATION (VCCR)}

The Vienna Convention on Consular Relations (VCCR) is a convention which has been ratified by 180 Sovereign Countries of the World. This conventions deals with the Consular Relations between different countries on the basis of bilateral agreements, traditions and customs in different countries. There are two important representatives of every country present in other countries. One of them is the Ambassador and the other is the Consul. Ambassador is the representative of the head of State while the Consul is the person designated to protect and assist the citizens of one country in the other. Both the representatives have immunity under the provisions of International Law. This particular resolution defines the rights and duties of Consuls in other countries.

The Vienna Convention on Consular Relations was presented in 1963 after the United Nations Conference on Consular Relations which was held at Vienna, Austria. However, this convention came into force in 1967. This convention has been followed and respected in almost all 180 countries that have ratified it. This convention comprises of total seventy nine articles. This convention allows the application of customary international law on matters which are not addressed in this convention. Some of the important articles of this convention include:-

Articles 5 related with functions of consul

- Article 23 is exception to the consular immunity because by virtue of this article a consular can be declared as a non desired person by the host country and if such consular is not taken back it can lose immunity after reasonable time

- Article 31 gives protection to the premises of the Consular

- Article 35 makes the communication between Consular and his home country privileged and protected.

- Article 36 is very important as it gives power to the consul to communicate with the persons from his/her sending country. If they are arrested, the host country is liable to communicate such arrest to the consul without any delay and such council will be allowed to visit the arrested national in the jails and can provide legal representation if required.

- Article 37 deals with the death, guardianship, trusteeship, accidents, etc. of nationals of consular's country within the territory of hosting country.

- Article 40 deals with the protection, dignity and respect of citizens of sending state.

- Articles 58 to 68 define the powers and functions of honorary consular.

Article 36 of the Vienna Convention is very relevant to Kulbushan Yadhav Case because it has been discussed many times during the arguments \& decision of the case. Pakistan has been blamed that it has violated the provisions of Article 36 because Mr. Yadhav has Consular Rights no matter how heinous are the crimes committed by him on Pakistani soil.

\section{DETAILS ABOUT KALBUSHAN YADEV (JADEV)}

Kulbushan Sudhir Yadav (Jadhav) was born on $16^{\text {th }}$ April 1970. He was born in Maharashtra India. He is son of a Police Officer that got retired from Mumbai Police India. Jadhav has a family in India with having wife and two children living in Mumbai. He joined Indian Defense Academy in 1987 and later got commissioned in 1991 in the 
Indian Navy. He joined Indian Intelligence Agency RAW in 2003. He visited Iran and Pakistan many times ever since. He established a small business in Iran for covering his identity. His identity in Iran and Pakistan was by the name of Hussain Mubarak Patel which was there on his documents.

He was serving as Commander in Indian Navy when he was sent to Pakistan on special mission to promote terrorism in the provinces of Baluchistan and Sindh to destabilize Pakistan. He was arrested from Baluchistan in March 2016 during a Counter Terrorism operation on which he confessed everything. His confession was shown on News Channels around the world. He disclosed the details of his activities in the confession he recorded in which he confessed about the killings and funding made by him during his stay in Pakistan while working for RAW (Research and Analysis Wing) which is the premiere intelligence agency of India.

India didn't accept his identity for a long time. His case proceeded in the Military Court in Pakistan which announced death penalty against him. On that India approached international court of Justice and made a fictitious story that he is a retired Naval Officer of India that was kidnapped from Iran. India denied his involvement in terrorist activities in Pakistan after a long time.

Jadhav's arrest helped Pakistani Authorities to diffuse hundreds of terrorists involved in anti-Pakistan activities in Baluchistan and Sindh Provinces. He met all the wanted criminals that were involved in funding nationalist movements against state. He was also involved in some bus attacks and attacks on officers in Baluchistan. Most of the activities conducted by Jadhav were between 2013 to 2016. Since Jadhav is an officer and High Profile terrorist, his arrest gave a setback to Indian Intelligence Agency RAW in Pakistan which has curtailed its operations to a great extent in Baluchistan and Sindh Provinces ever since.

\section{CONCLUSION}

This world is a beautiful place to live if we have peace and progress around us. It is true that countries have disputes for gain of power, money, resources and land over other countries at times. But that doesn't mean that a country has right to invade another country against the provisions of UNO resolutions and other international laws.

All the countries that are signatory to various treaties and conventions are duty bound to comply with the terms of such laws. If by virtue of decision in Kulbushan Yadhav Case, Pakistan has been blamed for violating the provisions of Article 36 of the Vienna Convention on Consular Affairs, it means all the countries that have ratified the same convention are also bound to give consular access to terrorists which are arrested in their countries.

There is a huge debate since $9 / 11$ that terrorists are not the people that should be consider humans. They should not be given rights equal to POWs or persons involved in minor offenses related with immigration laws. Rather they have to be treated differently and deterrantly so that the rest of the world remains safe from the atrocities of such terrorists and their activities. No civilized country in the world is ready to give consular access to any terrorist killing innocent people on its soil. But this judgment has set a precedent by virtue of which every country will now consider terrorists as humans and they may be given consular access in line with the provisions of Article 36 of Vienna Convention on Consular Affairs.

As far as arrests of Indian agents is concerned, it is not only Pakistan rather Indian Agents are frequently arrested from Asian as well as European Countries for spying illegally for no just reasons. This case is a unique one because in this case a High ranking officer has been arrested being involved in such activities and the matter has been argued in the International Court of Justice. Further a new precedent has been set by the Judgment in the captioned case which may influence the peace activities around the world in the times to come. It is time that Countries Around the world should focus on bringing a new convention related with the punishments and rights of terrorists rather than allowing them to have consular access under Article 36 which is for ordinary innocent citizens and not specifically for terrorists.

\section{BIBLIOGRAPHY}

1. Kulbhushan Jadhav https://en.wikipedia.org/wiki/Kulbhushan_Jadhav

2. Yadav - One of many RAW operatives caught in Pakistan https://www.thenews.com.pk/print/109024-Yadavone-of-the-many-RAW-operatives-caught-in-Pakistan

3. Jadhav Case Judgment https://www.icj-cij.org/files/case-related/168/168-20190717-PRE-01-00-EN.pdf

4. Jadhav (India V. Pakistan) https://www.icj-cij.org/en/case/168

5. Vienna Convention on Consular Relations https://en.wikipedia.org/wiki/Vienna Convention on Consular Relations

6. Consul (Representative) https://en.wikipedia.org/wiki/Consul_(representative) 